\title{
<総＼cjkstart説 $>$
}

\section{日本におけるHBワクチン対策の現状と問題点}

\begin{abstract}
矢野 右人
要 旨：B 型肝炎ワクチンを用いた B 型肝炎ウイルス (HBV) 感染予防対策は，その目的，方 法ともに世界の趨勢とかけ離れた日本固有の対策として定着している。すなわち，世界的に見 ると EPI(expanded program on immunization)に組み入れた universal vaccination で次世 代の人々すべてを受動免疫状態にして母子感染，水平感染ともに防御し，HBV 感染の撲滅を 目的としているのに反し，日本では HBV キャリアの母より出産した児にキャリア防止目的の ための接種に限られている.HBワクチン接種法も世界的には生後可及的速やかに接種するの が常識になっているが，いまだ日本では生後 2 力月後よりの接種である. 最近の WHO 肝炎 会議でも世界的 strategyに取り残され，議論にも入れない状態である.今世紀の半ばには universal vaccinationの効果が予測通りであれば，世界中多くの国では母子感染はもとより 水平感染による劇症肝炎も撲滅されることになる，日本だけが取り残されることなく，世界的 strategy に沿った HB ワクチンによる予防体制へ変更しなければならない.
\end{abstract}

\section{HB ワクチン対策の歩み}

$\mathrm{B}$ 型肝炎は感染域が世界中に広がりをもち，とくに 東南アジアでの持続感染率，いわゆるキャリア率が高 いことで知られている. 本感染の根本的予防法とし て，1986 年 B 型肝炎キャリアの血液より精製した HBs 抗原を用いた血液由来 HBワクチンが, 続いて 遺伝子組み換え HB ワクチンが開発され実用化した。 当時よりワクチン開発途上では日本は先導的役割を演 じてきた. HBV 母子間感染の実態解明がもっとも進 んでいたわが国では, HBe 抗原陽性の母より生まれ た児のみに $\mathrm{HB}$ キャリアが成立するというデータの 下，1980 年頃よりこれらの児を対象に高単位 HB グ ロブリン(HBIG：Hepatitis B Immunoglobulin)を用 いた受動免疫による予防法が試みられるようになっ た.

当時より開発中であった HB ワクチンの実用化が 待たれた。1986 年血液由来ワクチンが認可されると 同時に国の政策医療として HBV キャリアのうち HBe 抗原陽性の母より生まれた児に限って HBIG と HB ワクチンを用いた受動一能動免疫法で予防法が確 立された。

しかし，わが国の HB ワクチンによる肝炎予防対 策はこの時点で完成したものとの認識で, 研究も停止 した状態であり，わずかに肝炎ウイルス駆除療法に

国立病院長崎医療センター
HB ワクチンに関する研究が限定されているに過ぎな w.

一方, 台湾, 韓国, 中国など $\mathrm{HBV}$ キャリア率が高 い国々では対象を広く selected vaccinationより universal vaccination への方向付けがなされた。これは $\mathrm{HBV}$ キャリアが多いことのみならず, HBIG あるい はスクリーニングに要する費用が高額であることにも よる。

\section{HB ワクチン接種法}

日本に扔ける母子感染予防の具体的方法は, $\mathrm{HBe}$ 抗原陽性の母より出産した児を対象に生後 1 週以内に HBIG を投与し受動免疫状態とし, 生後 2 力月目に 2 回目の HBIG と初回の HB ワクチンを接種し, 生後 3 力月, 5 力月目に第 2 回, 第 3 回目の HB ワクチン を接種し予防法を完了する方法である. 投与法の理由 は，生直後に HBIG を投与することにより，児がす でにキャリアになっていた場合, 抗原抗体反応で著明 な副作用が出現する可能性があるとの強い主張が一部 の学者より提唱されたことによる. また, 過去に日本 ではいかなるワクチンも生直後に接種した例がないこ とがその理由であった。しかし, 世界的には出生直後 の HB ワクチン接種が常道になり, 早期の能動免疫 が可能で副作用も認められないなどのデータが集積さ れてきた。また，発展途上国では経済的理由による HB ワクチンン単独予防法が試行され, 効果に扔いて 
も HBIG 併用予防法に引けをとらない実績が積み上 げられてきた。これらの成績より，WHOやユニセフ より原則として生直後 HB ワクチン初回接種, 1 力 月, 6 力月後の計 3 回接種法が勧告されるようにな り, 日本の生後 1 週以内の HBIG, 2 力月後よりの $\mathrm{HB}$ ワクチン接種という世界戦略と乘離した予防法が 固定した1〜4).

\section{3. 接種対象者}

既に日本では, キャリア成立は HBe 抗原陽性の母 より出産した児に限られるとの成績がコンセンサスと して受け入れられていた。台湾, 韓国でのデータで は, 水平感染よりキャリア成立も否定できないことも 理解されていた. 現在の日本の HBVの $95 \%$ が genotype Cであり，他国と異なることなど知られて いない時代のことである. 日本では母子感染予防が即 キャリア予防であるとの立場より, 対象は e 抗原陽性 の母より出産した児に限定されることになった. 1995 年より対象者は, $\mathrm{HBe}$ 抗原陰性の母親でも HBs 抗原 陽性であれば接種対象者に広げられた。約 3 倍の対象 者になったものの全出生者の $1 \%$ 程度に過ぎない.

肝癌が多い東南アジア諸国にとっても，B 型肝炎予 防対策は重要な政策として, WHO 西太平洋事務局の 指導もあり頻繁な対策会議がもたれ，日本とほとんど 時期を同じくして HB ワクチン対策が開始された.

しかし，HBキャリア率が 10\%あるいはそれ以上 に及ぶ東南アジア諸国にとり HBIG があまりにも高 価であるとともに, 出産時母子の HBs 抗原, HBe 抗 原のスクリーニングに関するシステム経費ともに莫大 なものになるため経済性から見ても, 全出産児にスク リーニング無しでワクチンを接種するいわゆる universal vaccination で対応されるようになった.

$\mathrm{HBV}$ キャリアが比較的少ないとされる先進国でも HB ワクチン対策は重点的にとりあげられ，米国では 1988 年全妊婦の HBs 抗原スクリーニングが実施さ れ, 陽性者からの出産児に HB ワクチンが接種され るようになり，1991年からは全出産児に接種する universal vaccination に切り替えられた5〜7).

世界的に universal vaccination が実施されるにし たがって，WHO を中心にEPI(Expanded Program on Immunization)に含めた他のワクチンとの同時投 与が検討されてきた。

1992 年 WHO および UNICEF はすべての新生児 および青少年にHB ワクチンを接種する勧告を行っ た。勧告以来, 1999 年までの 7 年間に 108 力国で universal vaccination が開始され世界中の新生児の 約半数に HB ワクチンが接種されるまでになった。 先進国で universal vaccination が実施されていない のは，日本と英国程度である8 12).

\section{4. 日本での HB ワクチン接種の現況}

日本に扔ける HB ワクチン生産量を(図 1)に示す. 認可された 1986 年以来, 15 年間に $5286 l$ のワクチン が生産されている，小児用を除くと年間生産量は平均 $340 l$ で, 標準的 $0.5 \mathrm{~m} l, 3$ 回接種では毎年 22 万人 程度が接種を受けていることになる，小児用 HB ワ クチン生産量(図 2) は年平均 50559 本であり，これは 約 16800 人分/年である. 出生数が 137 万人として生 産ワクチンがすべて使用されているとしても, 全出生 児の $1.2 \%$ 程度である.世界的視野から見るとuniversal vaccination で新生児の能動免疫カバー率が年 とともに急激に上昇してきている中，日本の HBs 抗 体保有者は他国と比較にならないほど少数派になりつ つある。

\section{HBV 感染の問題点}

B 型肝炎は, 最近では血液由来感染症として性交涉 による感染が最も多数を占める。しかし，医源性感染 も後を絶たず，院内感染としても問題化している．既 知のウイルス肝炎の中で最も症状が激しく劇症肝炎に 移行, 死の転帰をとる頻度が最も高い肝炎でもある. また, HBV DNA は宿主に integrateするウイルス として, C 型肝炎に比し感染後の根絶は困難な肝炎と される.

今後現在の対策でとどまるならば，20 年後には世 界中の大多数の国での若年者は HBV 抗体保有者で占 められるのに反し, 日本人の抗体保有者は少なく,い よいよ大きな開きとなる. HBV 侵淫地とされた中 国, 台湾, 韓国などの若者に比し, HBV 感染に抵抗 性のない劇症肝炎の危険にさらされやすい国民になっ てはいけない13,14)。

\section{HB ワクチン政策への提言}

WHO 西太平洋事務局を中心に HB ワクチン対策 は長い間討論され，その strategy は確定している。 現在はカバー率を高めるための方法論, ワクチンの供 給, 経済性の問題が議論されている. 最近も2002 年 6 月にWHO-B 型肝炎予防対策会議が開かれたが, あまりにも国際的 strategy と乘離した日本の現状で は議論にも入れない状態である。つまり, 対象例がキ ヤリアの母より出産した览のみであること, 生後 2 力 月後のワクチン接種であることの 2 点に尽きる. 当時 

$6: 56$
肝
臟
44 巻 2 号（2003）

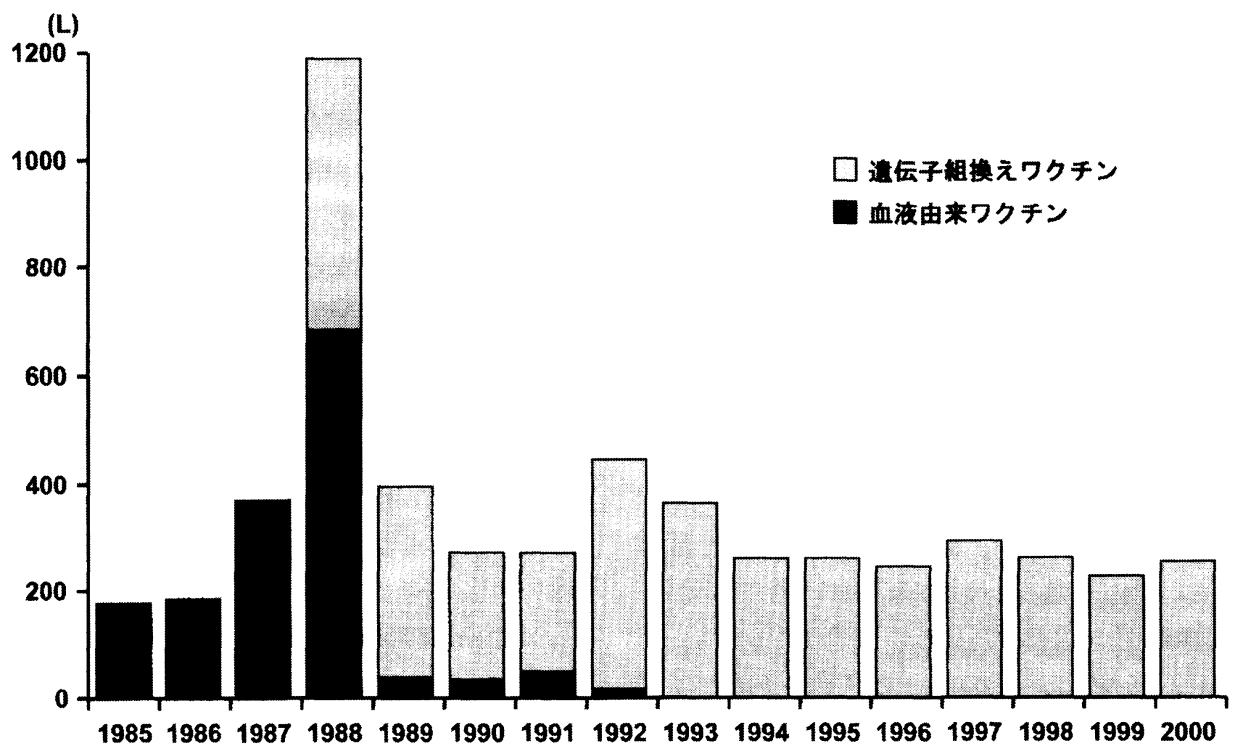

図 1 日本における HB ワクチン製造量の推移

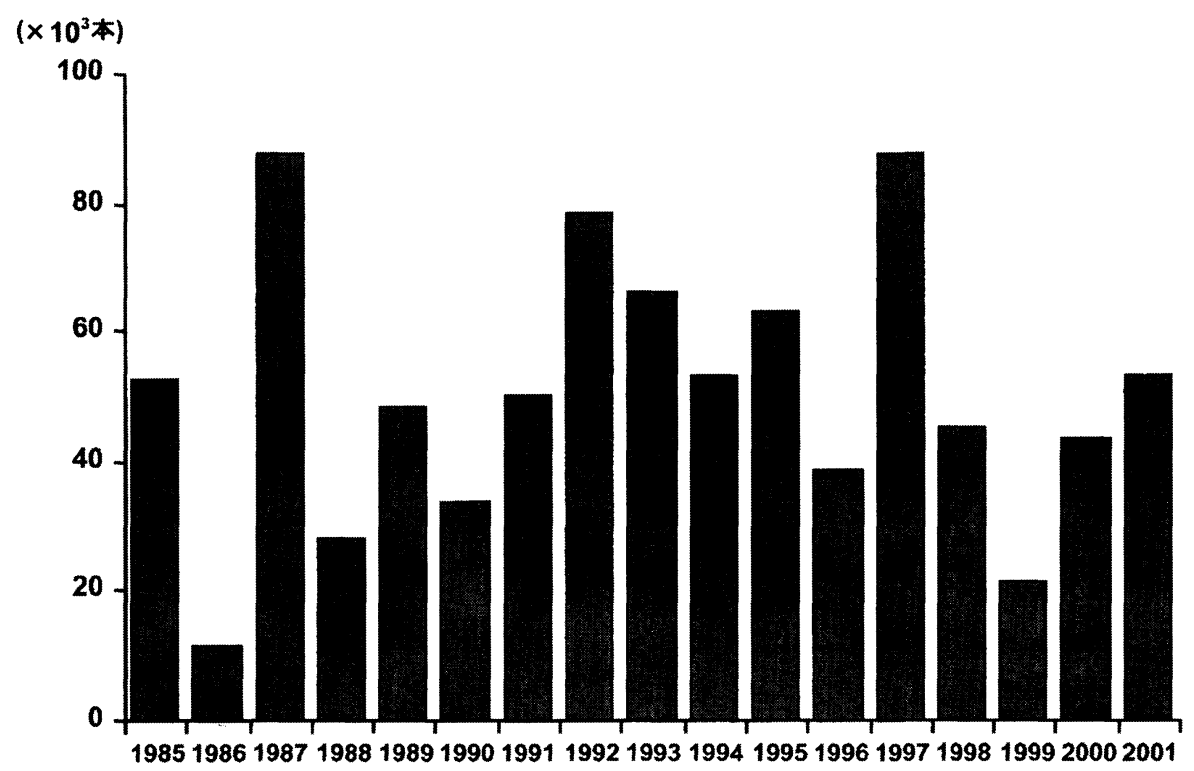

図 2 小児用 $\mathrm{HB}$ ワクチン $(0.25 \mathrm{~m} l)$ 生産量の推移

の日本の考え方, キャリア防止のみであればこの方策 でよいかもしれない.しかし, 劇症肝炎 B 型が今で もこれだけ騒がれている中，キャリア防止のみにとど まらず水平感染対策も含め, 世界に通用する方策, つ まり全新生児を対象に生直後の HBワクチン接種の 政策確立が必要である。
文献

1) Robert E, Mark A. Kane, Nuncy Muller, et al : Infant and adolescent hepatitis B immunization up to 1999 : a global overview. Vaccine 19:1026-1037, 2001

2) Paolo Bonanni: Universal hepatitis B immu- 
nization: infant, and infant plus adolescent immunization: Vaccine $16: \mathrm{S} 17-22,1998$

3) Paolo Bonanni, Pietro Crovari: Success stories in the implementation of universal hepatitis $B$ vaccination: an update on Italy. Vaccine $16: \mathrm{S} 38-42,1998$

4) Hus-Mei Hus, Chih-Feng Lu, Shin-Chwen Lee, et al : Seroepidemiologic Survey for Hepatitis B Virus Infant in Taiwan: The effect of Hepatitis B Mass Immunization. The Journal of Infectious Disease $179: 367-370,1999$

5) Coleman PJ, McQuillan GM, Moyer LA, et al : Incidence of hepatitis B virus infection in the United States, 1976-1994: estimates from the National Health and Nutrition Examination Surveys. J Infect Dis 178: 954-959, 1998

6) Centers for Disease Control and Prevention. Hepatitis B virus: a comprehensive strategy for eliminating transmission in the United States through universal childhood vaccination : recommendations of the Immunization Practices Advisory Committee (ACIP). MMWR Morb Mortal Wkly Rep 40:1-25, 1991

7) Centers for Disease Control and Prevention. Immunization of adolescents: recommendations of the Advisory Committee on Immunization Practices, the American Academy of Pediatrics, the American Academy of Family Physicians, and the American Medical Associa- tion. MMWR Morb Mortal Wkly Rep $45: 1-$ 16, 1996

8) Stroffolini T, Chiaramonte M, Craxi A, et al : Baseline sero-epidemiology of hepatitis $B$ virus infection in children and teenagers in Italy. A survey before mass hepatitis $B$ vaccination. J Infect $22: 191-199,1991$

9) Stroffolini $T$, Pasquini $P$, Mele $A$ : $\mathrm{HBsAg}$ carriers among pregnant women in Italy. results from the screening during a vaccination campaign against hepatitis B. Public Health $102: 329-333,1988$

10) Kane MA : Status of hepatitis B immunization programs in 1998 . Vaccine $16: \mathrm{S} 104-$ 108, 1998

11) Van Damme $P$, Kane M, Meheus $A$ : Integration of hepatitis $B$ vaccination into national Immunization Programs. BMJ 314:10331036, 1997

12) Mele A, Rosmini $F$, Zampieri $A$, et al : Integrated epidemiological system for acute viral hepatitis in Italy (SEIEVA) : description preliminary results. Eur J Epidemiol 2:300-304, 1986

13）白木和夫：国際的にみた B 型肝炎ウイルス感染 防止戦略. 小児感染免疫 $11: 79-383,1999$

14）六波羅明紀，清澤研道：B 型肝炎ワクチンをどう 使いこなすか. 消化器の臨床 $4: 390-395$, 2001 